\title{
Providing new opportunities to adolescent girls in socially conservative settings: The Ishraq program in rural Upper Egypt
}

\author{
Martha Brady \\ Population Council \\ Ragui Assaad \\ Population Council \\ Barbara L. Ibrahim \\ Abeer Salem \\ Population Council \\ Rania Salem
}

See next page for additional authors

Follow this and additional works at: https://knowledgecommons.popcouncil.org/departments_sbsr-pgy

Part of the Demography, Population, and Ecology Commons, Family, Life Course, and Society Commons, Gender and Sexuality Commons, International Public Health Commons, and the Women's Health Commons How does access to this work benefit you? Let us know!

\section{Recommended Citation}

Brady, Martha, Ragui Assaad, Barbara L. Ibrahim, Abeer Salem, Rania Salem, and Nadia Zibani. 2006.

"Providing new opportunities to adolescent girls in socially conservative settings: The Ishraq program in rural Upper Egypt." New York: Population Council. 


\section{Authors}

Martha Brady, Ragui Assaad, Barbara L. Ibrahim, Abeer Salem, Rania Salem, and Nadia Zibani 



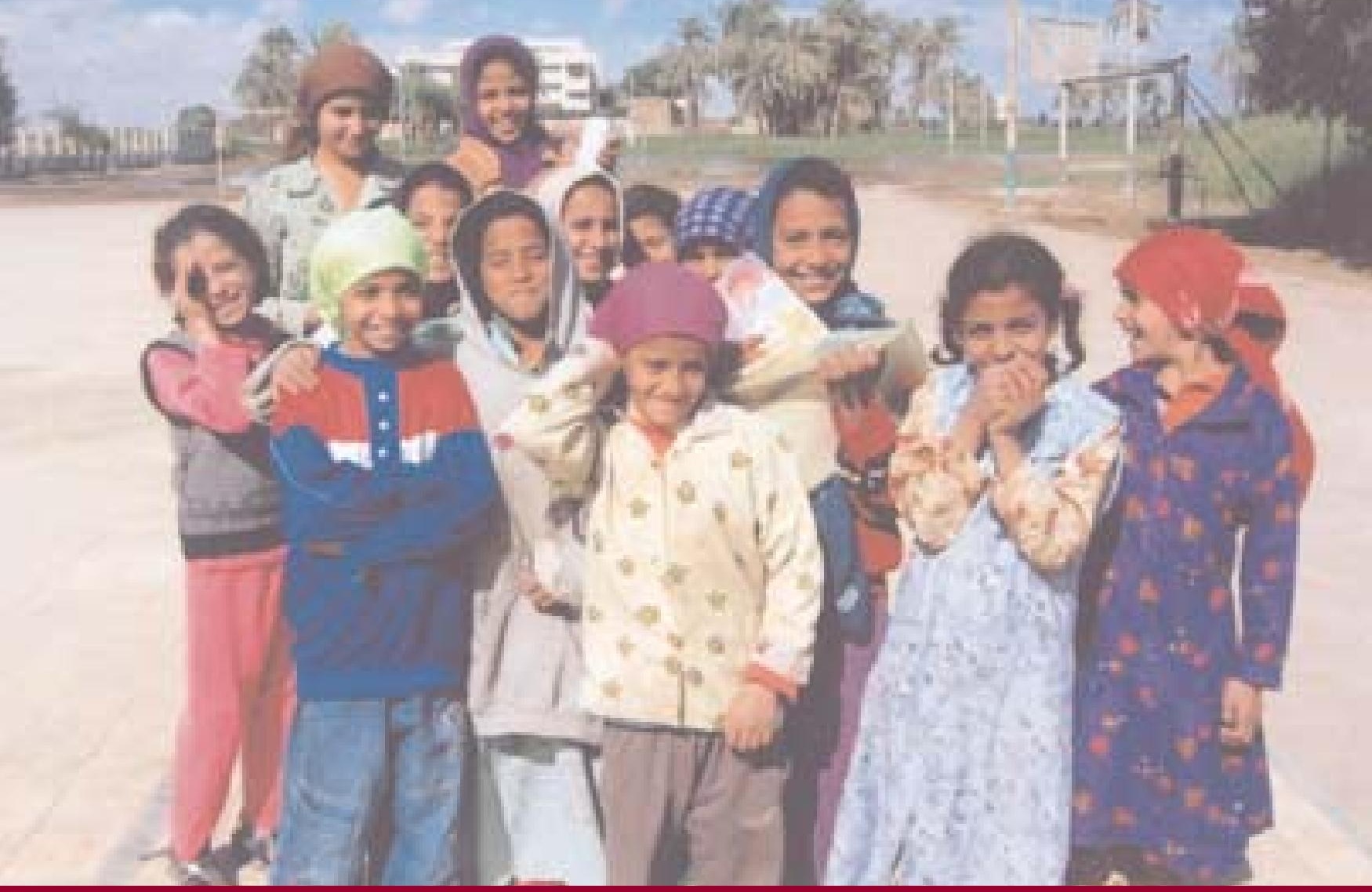

The Ishraq ("enlightenment") program in rural Egypt has ambitious goals for adolescent girls: to create safe spaces for girls to learn and play in their communities, to increase their literacy, and to promote positive social norms related to their abilities and life opportunities. 


\section{In a rapidly globalizing and technologically}

driven world, children who miss out on basic schooling or whose childhood is interrupted by marriage will be left behind. In rural areas of Upper Egypt, that disadvantaged group is largely made up of adolescent girls. Much has changed in Egypt over the last 20 years, reflected in expanded investments in education and rising levels of literacy, improvements in the infrastructure of rural communities, vigorous growth in the economy, and expanding civic participation. Girls in rural Upper Egypt, however, remain socially isolated within their families, without a voice in their communities, burdened with heavy domestic chores, and subject to harmful traditional practices like child marriage and female genital cutting.

Although all of Egypt's 13 million boys and girls ages 10 to 19 face challenges in safely reaching adulthood, rural adolescent girls of Upper Egypt are among the most disadvantaged youth. It is for these girls that the Ishraq program was begun in 2001 . What follows is the story of the first phase of the program and the remarkable changes it has fostered in a short time. 

nities, growing self-awareness, and increased knowledge about the world. For girls in rural Egypt, these prospects often never arrive.

Puberty, rather than opening doors to new opportunities, consolidates girls' disadvantage. Apart from their lesser access to schooling, Upper Egyptian girls are at risk for early marriage, female genital cutting, and violence within the household. Rural girls work long hours in the home and in the fields. Fears for their social reputation restrict mobility and community participation. Girls have little access to or time for "recreation": only 5 percent of rural girls reported having played sports in the previous day compared to 56 percent of boys. Added to this is a climate in which civic engagement is not encouraged for young people, and fewer than 5 percent join clubs or other organizations.

Boys' and girls' prospects diverge sharply at puberty. Boys can seek out alternative avenues for expression, socializing, and learning public roles-at sports clubs and on street corners. Girls' main outlet for interaction outside the family is the school. Thus withdrawal from schooling means more than forfeiting a formal education and skills. Out-of-school girls miss out on the pleasure and practical support of interaction with peers, exposure to positive adult role models (inspiring teachers or women they would "like to be like"), and access to a place outside the home where their presence is safe and welcome and they can begin to be part of community life.

The degree of success with which rural girls make the transition to adulthood with greater resources and freedom than their mothers will largely determine whether or not Egypt reaches its national Millennium
Development Goals related to poverty alleviation, a more equitable distribution of income across households, improved educational attainment, reductions in maternal and child mortality, and promotion of better reproductive health. For that to happen, these forgotten girls need to have advocates and lifelines. Cycles of illiteracy, poor job prospects, and social isolation can be broken, but doing so requires concerted efforts to reach girls early-with robust programs-before marriage and childbearing consolidate their isolation and poverty.

\section{>>Taking Action to Reach Girls Left Behind}

This picture of exclusion and vulnerability was the catalyst for a pilot program locally known as Ishraq, undertaken in four rural villages of the $\mathrm{Al}$ Minya governorate in Upper Egypt. In 2001 four nongovernmental organizations (NGOs) with a long tradition of working in Egypt-Caritas, CEDPA (the Center for Development and Population Activities), the Population Council, and Save the Children, with critical support from two key government agencies, the Ministry of Youth (recently renamed the Supreme Council for Youth) and the National Council for Childhood and Motherhood (NCCM)-launched a joint effort. The four NGO partners became the "Ishraq resource team" responsible for introducing the Ishraq program and evaluating its success. They remain a critical resource for transferring the knowledge and experience gained through Ishraq to other institutions inside and outside of 
Ishraq's primary objectives are to:

Create safe public spaces for girls in their communities and lay the foundation for citizenship

Improve girls' functional literacy, recreational opportunities, life skills, health knowledge and attitudes, mobility, basic livelihoods information, and civic engagement

Positively influence social norms concerning girls' abilities and life opportunities

Improve local and national decisionmakers' support for girl-friendly measures and policies 


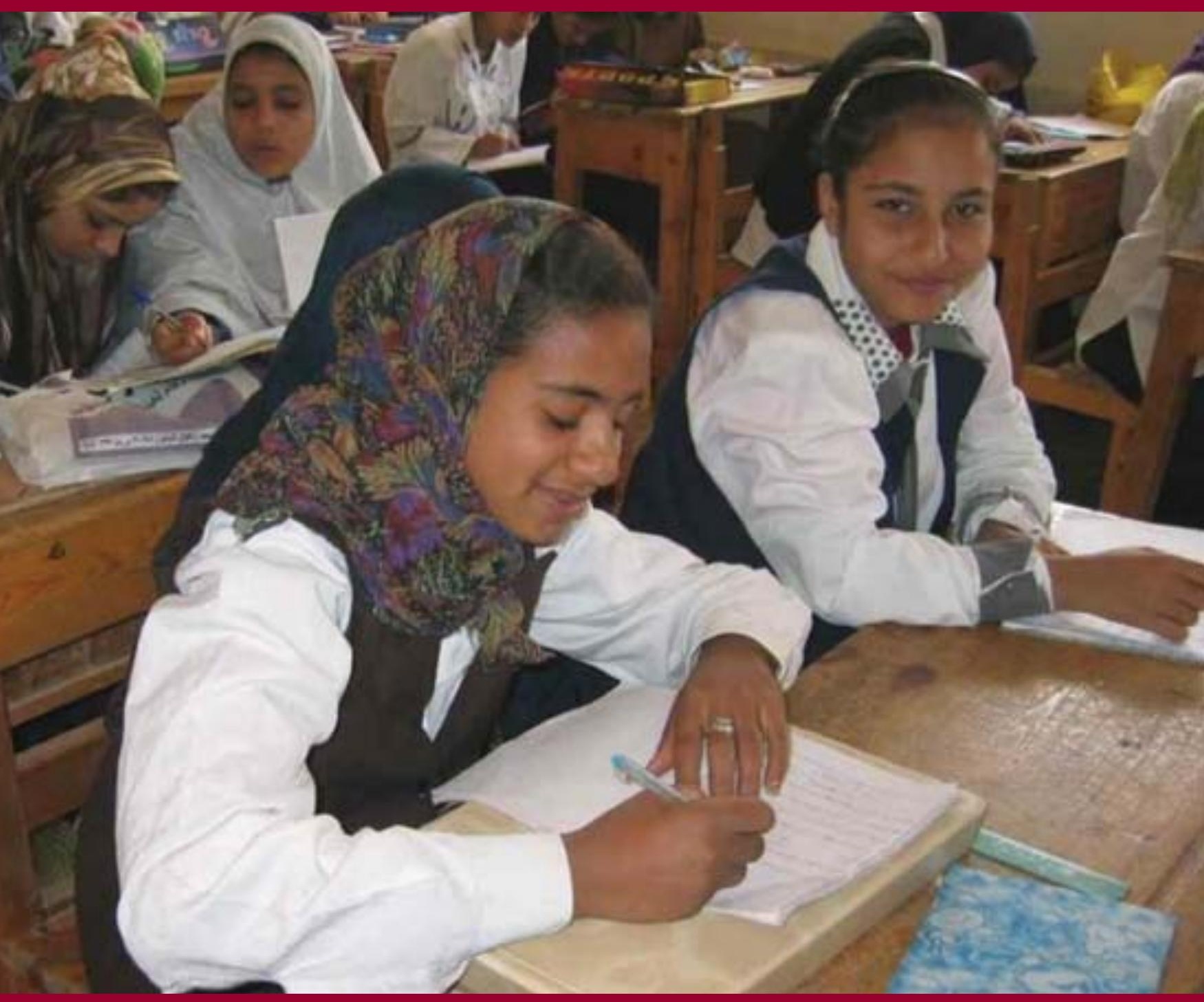

Ishraq aims to improve the lives of rural out-of-school girls by providing them with safe meeting places and a second chance for education. Ninety-two percent of Ishraq participants who took the government literacy exam passed. 
Egypt that seek to provide new opportunities to girls in socially conservative settings.

Ishraq had ambitious goals. It sought to transform girls' lives by changing gender norms and community perceptions about girls' roles, build their skills, and bring them safely and confidently into the public sphere. The program aimed to establish protected and comfortable "girl-friendly" spaces in the communities where girls could meet, learn, play, develop, and practice leadership.

Ishraq offered not a one-off course, but a series of interlocking opportunities-literacy classes, life skills training, community engagement, and sports. Girls ages 13 to 15 from four villages met four times a week for three-hour sessions in youth centers or schools in groups of about 25 members each. In each village about 50 girls participated and within the first year, as community enthusiasm grew, there were waiting lists of interested girls. Given the small populations in these villages, this number represents a noteworthy proportion of eligible girls. The 30-month program offered girls sufficient exposure to enable them to pass their literacy exam and enter or return to school; the length of the program also had the benefit of getting communities and families accustomed to girls' new roles and their freer movement outside the home.

\section{> A Agents of Change: Ishraq \\ Promoters as Role Models, Mentors, and Teachers}

Mindful that adolescent girls cannot make changes on their own, the resource team recruited young female secondary-school graduates from the community and trained them as program leaders, known as promoters. Promoters served as teachers, role models, girls' advocates, and providers of moral support. They became the critical link between girls, their families, and the Ishraq resource team-providing interpre- tation in both directions, quelling the fears of hesitant parents on the one hand, and articulating and addressing girls' cultural concerns on the other.

In order to reach the most vulnerable girls, Ishraq based the timing of meetings both on the girls' schedules, which are often filled with work and domestic chores, and on availability of space in the village. Notably, the community and youth centers most commonly used were never officially offlimits to girls but until the initiation of the Ishraq program, girls and women were rarely seen in these nominally public spaces.

Ishraq aimed to develop a range of skills while increasing girls' self-confidence, building their leadership abilities, and raising their aspirations. Cognitive development was promoted through training in language, numeracy, and problem solving. Confident physical expression was encouraged through games, movement, and sports. Girls' social capital and negotiation skills were augmented through a life skills component that sought to build their capacity for interpersonal relations, offered visits to other villages, provided accurate health information, and introduced them to the rights and materials (birth certificates and identification cards) of citizenship.

Recognizing that interventions aimed solely at girls would have only a minimal effect on the norms that govern gender behavior and restrict options for girls, the Ishraq team prioritized community engagement from the outset. The team worked simultaneously with adolescent boys, parents, and community leaders such as priests and mosque imams, physicians, mayors, and governorate health and education officials. To address boys' domination of girls in the home and their harassment of girls in public, Ishraq introduced CEDPA's New Visions curriculum targeted to adolescent boys. This communityengagement approach was difficult to carry 


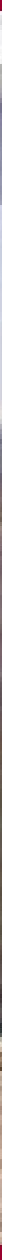

Organized sports and play were groundbreaking. Ishraq's sports component was designed to build girls' confidence and sense of ownership of their bodies while encouraging freedom of movement and physical expression. 
out and took time to develop-at least six months at the start-but resulted in a commonly agreed framework of values and goals.

\section{>>Ishraq Program: Literacy, Life Skills, Sports, Livelihoods}

Ishraq adopted Caritas's Learn to Be Free literacy curriculum, one of the most successful programs of its kind in Egypt. Learn to Be Free relies on active discussion between teachers and girls as the primary means of imparting information and knowledge. Promoters were readily trained to introduce topics using audio-visual aids designed to stimulate learning; each student was required to contribute a number of times in each session and was encouraged to express her own opinions and respect the views of others. Learn to Be Free classes were held twice a week, offering instruction in Arabic, math, health, environment, and income-generating skills. A basic goal of the classes was to foster girls' entry or reentry into the formal educational system.

CEDPA's New Horizons life skills program was included because it had been closely adapted to the condition of girls in Upper Egypt. The courses sought to strengthen girls' ability to attain their sexual and reproductive rights-increasing the probability that they would make later, safer marriages of their choice-and to eliminate harmful traditional practices. Girls discussed the information provided and proposed ways to challenge the tactics that family members commonly use to control wives and daughters through beatings and abusive language, female genital cutting, and pressure for early marriage.

Whereas the literacy and life skills programs were tailored from existing resources, Ishraq's sports component was a novel and groundbreaking activity within these villages, and as such had no blueprint to fol- low. Introducing sports programs for adolescent girls in culturally conservative settings has long been a challenge. Ishraq began with indigenous games that are sedentary and played indoors. As the program progressed, activities such as jumping jacks, running, and kicking soccer balls helped girls feel more comfortable with their bodies-of particular importance during puberty when many girls, having been subjected to physical confinement and female genital cutting, may not feel comfortable enjoying their bodies and finding expression through them. Parents, male siblings, and community representatives were consulted at all stages to ensure that girls' right to play was protected and had their families' support. It was crucial that girls' uniforms were modest and that basic sports skills were taught in an enclosed space, at the youth center away from prying eyes.

Table tennis proved to be well-suited to girls' social requirements, as it allows for discreet dress and is relatively inexpensive to organize and culturally familiar. In collaboration with the International Table Tennis Federation and its local Egyptian affiliate, table tennis became a key element of the Ishraq sports program, popular among both girls and their parents; in some circumstances boys and girls participated together in free play and tournaments. Whereas soccer as a team sport did not find favor, the girls continued to enjoy kicking the ball to one another and relished the vigorous exercise.

In addition to sports and classroom learning, girls from poor families expressed an interest in learning both home-based and vocational skills that would assist them in their future roles as mothers and providers of household income. Girls were eager to learn cheese and jam making, sewing, and needle work, and promoters taught them these skills. Some participants 
wanted to learn nontraditional and commercial skills: apprenticeships were established for girls who wished to learn about electrical appliance repair and hairdressing.

\section{>>Key Achievements: Changes for Girls and Their Communities}

In its first 30 months of operation, Ishraq not only changed the lives of girls but, owing to the comprehensiveness of the intervention and the relatively high proportions of eligible girls in each community participating, it altered how girls are "seen" by communities and policymakers in Upper Egypt.

Ishraq was rigorously evaluated by means of a longitudinal survey, using a pretest/post-test design, of all out-of-school adolescent girls ages 13 to 15 in the four Ishraq villages and in an additional two control villages. The survey measured knowledge of vital health and human rights issues, gender role attitudes, literacy and educational aspirations, friends and peer networks, work and livelihood skills, restrictions on mobility, sports participation, and key issues related to marriage. By comparing responses before and after the introduction of Ishraq (and comparing these results with changes over time in the control communities), it is possible to discern the degree of change attributable to participation in Ishraq. Here is some of the evidence.

\section{Evidence of change in girls' lives and their communities}

- Initially the "safe spaces" concept was based on the observation that girls lacked a dedicated place where they could meet with friends and engage in independent activities without interference from family or male peers. In the course of the Ishraq program, community members became accustomed to seeing girls travel from their homes to the community center and recognized and accepted their right to dedicated girls-only spaces in the community.

- The purpose of Ishraq was not simply to provide girls with basic literacy skills, but to facilitate their return to formal education through the public school system.

- Ninety-two percent of Ishraq participants who later took the government literacy exam passed, and 67 percent of girls who completed the program have entered school. In the second round of Ishraq, the entry age will be lowered to 11 years, increasing the possibility that a higher proportion of girls who pass the exam are young enough to enter secondary school.

- Approximately one-half of Ishraq participants have joined a local club or association since participating in the program.

- Ishraq has trained skilled young promoters who have become active citizens. By the end of the pilot program, some promoters had organized women's associations in their communities, joined political groups, and accepted local leadership positions.

- Group discussions with parents of Ishraq girls suggest that they have adopted increasingly progressive views toward girls' roles, rights, and capabilities.

- The Ishraq program worked with local authorities to ensure that girls were offered identification cards in the form of a health or birth certificate-a critical first step in developing an active citizenry as well as offering some protection from underage marriage, which is often justified on the basis that a girl's age is not actually known.

- Girls are more certain of their rights and more confident in their ability to assert and defend them. Upon completion of the program, girls reported higher levels of self-confidence: 65 percent said they often felt "strong and able to face any 


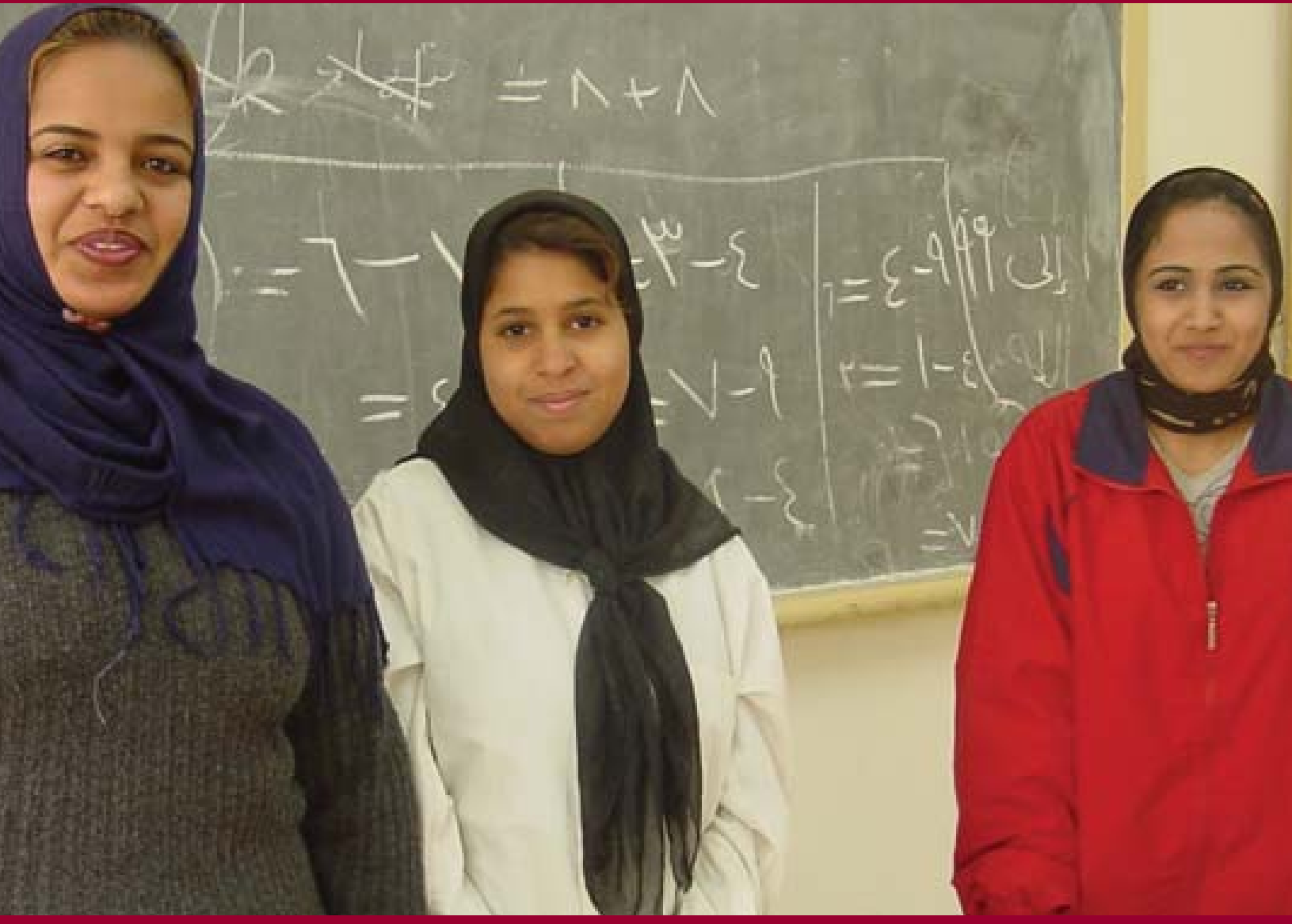

Ishraq recruits young female secondary-school graduates from the community and trains them to be program leaders, known as promoters. Promoters serve as teachers, role models, girls' advocates, and providers of moral support. They become the critical link between girls, their families, and the Ishraq resource team. 
problem." Participation in Ishraq has led to a reduction in the number of girls who report they feel they have to obey their brothers. Participants also expressed a desire to marry at older ages and have a say in choosing their husbands.

- Ishraq has greatly reduced girls' support for female genital cutting. All girls who completed the full 30 months of participation said they would not have their daughters undergo genital cutting. (Because the decision to perform the procedure also involves the paternal grandmother and other members of the family, this change in attitude does not guarantee the elimination of the practice among the daughters of Ishraq graduates, but it is clearly an important step in that direction.)

- There was a dramatic increase in girls' interest in sports; while less than 2 percent of girls had ever participated in sports prior to Ishraq, at the end of the program 94 percent said they enjoyed playing sports and 99 percent would encourage their daughters to play. Girls reported benefiting from playing sports: 90 percent claimed improved physical health, and 59 percent claimed improved mental health.

- Participation in Ishraq helped girls keep and gain friends. This achievement is crucial, as part of girls' poverty is the decline in friendship networks that begins around puberty and is further reduced after marriage. Ishraq helped girls expand their social circles by providing them with opportunities to form and sustain friendships.

\section{>>Consolidating Change}

Ishraq is poised to move from the innovative pilot phase described here to a larger program with the potential to change the lives of thousands of girls throughout Upper Egypt. That expansion, however, is unlikely to follow the typical path of scaling up. The target group of poor, unschooled adolescent girls can neither drive demand nor shape program delivery. This group has for some time been entitled to a number of constitutionally guaranteed rights, such as the right to schooling, to health insurance and health care, to a voluntary marriage at legal age, and to participation in the life of the community as full citizens with personal documentation. But adolescent girls have not been able to reliably access these rights up to now and instead have had to negotiate through the barriers of parents, cultural and marital customs, often unsupportive brothers and male peers, and an insensitive and inaccessible community structure.

Ishraq has demonstrated the feasibility-indeed in some cases the strong desire-for change in traditional communities with respect to girls' rights and the creation of new opportunities. Thus, a key objective of the Ishraq expansion is to reinforce reliable access by girls to their legally established rights by increasing the visibility of adolescent girls and respect for their capacities-first and foremost within their families, next within their communities and rural governorates, and finally at the level of national policymaking. The core resource team, with the support of the Ministries of Youth, Health, and Education, and the NCCM, will work together as allies, approaching clusters of communities and new governorates to generate interest in creating Ishraq-like programs.

The articulation of Egypt's national Millennium Development Goals is helpful to this process. It is vital that Ishraq is perceived as being aligned with national social and economic initiatives, such as the Girls' Education Initiative of the NCCM, which 


\section{Girls' Assessment: \\ In Their Own Words}

"Ishraq fulfilled our dreams to be educated, to be respected by our families and our communities!"

"I would have been married without [Ishraq]. We all would have. There are still parents who want to get us married."

“For the first time in my life I learned that girls have equal rights to education as boys. In the past my understanding was that girls did not need to be educated because they were going to marry."

"Now I am more active. I feel stronger. Sports are good. They make girls more aware of what's happening around them."

"I took every class seriously. Every class was not just learning letters, it was about the issues we live every day. We learned to cook, we learned to make yogurt, and we learned how to make sweets. Every day, I came home and taught everyone."

"I was traveling with my father to Assiut. It was my first big trip outside of Minya. There was a security check and they asked my father who I was. I pulled out my new identification card. The officer took it, looked at it, and then said, 'You are smart-it is important that you have' this identification card.' I felt so happy and proud-I felt I was someone, I counted." 
seeks to improve the educational status of girls in the most disadvantaged areas of Egypt. Ishraq's experience in converting youth and community centers to include space for girls and women is directly supportive of the Ministry of Youth as it seeks to improve girls' participation in youth centers, expand local capacity for development at the grass-roots level, and turn the youth centers into more inclusive community resources. A formal protocol signed with the Ministry of Youth dedicates specific times and spaces for Ishraq participants and other young women in village youth centers.

NCCM has also intervened with the Ministry of Interior to facilitate the issuance of national identity cards for girls when they reach age 16 and the issuance of birth certificates for girls who were not registered at birth. This step has led to a wider initiative to issue national identity cards to girls when they reach age 16 and to issue birth certificates for girls who were never registered at birth.

An essential investment in the pilot phase, and one that needs to be preserved in planning for the second phase, is the recruitment and training of female promoters and sports leaders. The recruitment of young women from low-income families in rural Upper Egypt and their training and performance as teachers, mentors, and earners are strong signals of change. They are the most permanent and influential heirs of the program apart from the graduates themselves. They carried a heavy burden of responsibility for protecting girls when conflicts arose with families and communities. The respect the community developed for them was often key in ensuring the girls could continue to participate.

It is critical that these energies not be lost to the community as Ishraq is introduced in new villages. These young female leaders need to be assured a place in village life and could profitably be engaged in the expansion process, conducting training of trainers and working in nearby villages. Thoughtful and sustained efforts are required to retain the talents and experience of these promoters even after they marry and have children.

One of the most valuable gains from Ishraq is the self-confidence and leadership skills gained by the graduates themselves. The graduates expressed a strong desire to continue to meet with each other, apply their skills, participate in village life, and retain assured access to youth and community facilities for group activities. Apart from the collective goals of the graduates, each girl has her own objectives. An Ishraq graduates' fund has been established that will combine individual grants (of about US\$25) with personal savings to finance continued schooling, skills building, or livelihoods training. Ishraq graduates will be encouraged to formulate plans for using these funds to further their development, thus contributing to their financial know-how.

\section{$>$ Benchmarks of Success in the Next Phase}

Ishraq has already set the stage for change in the original four communities. An additional ten new Ishraq villages have been organized. The Ishraq approach has challenged national-level decisionmakers to move substantially beyond conventional youth-serving initiatives, which direct their efforts to urban, older, and often male beneficiaries. Any on-site observer of the program sees the tremendous enthusiasm of the current group of participating girls, and the waiting lists for participation are also a testament to success. Yet, two questions always arise when evaluating programs for underserved groups: How far can it go? And, how do you know you have succeeded? 


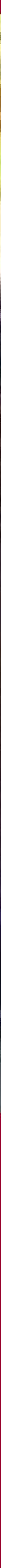




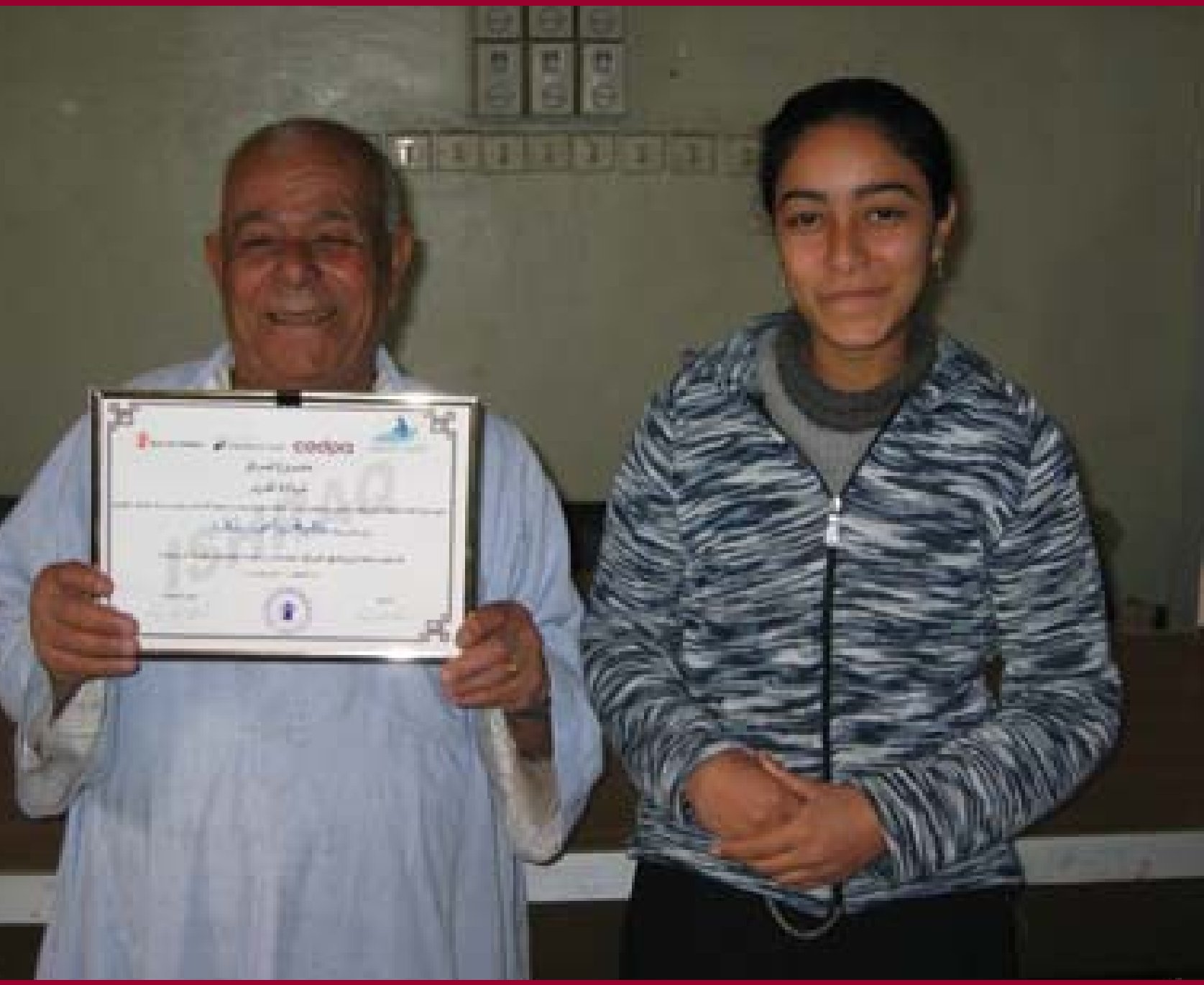

While parents were initially hesitant, they became supportive of the Ishraq program as their daughters began to benefit from their new knowledge and skills. 
The Ishraq resource team has established measures of success as it seeks to expand to several clusters of villages in three of the most traditional Upper Egyptian governorates. Measures of success for the next five years include the goal of reaching 20 to 30 percent of the eligible girls and families in each community. For most villages, this will require two or three rounds of recruitment of 50 girls at a time; priority will be given to selecting villages of intermediate size with between 250 and 650 eligible girls. This includes not only the poorer villages (size and poverty are often related), but also the majority of villages in the three governorates targeted. An effort will be made in each new village to forge a more formal "community contract." This contract will specify the requirements incumbent upon a village for its inclusion: the availability of a facility with dedicated learning and playing space for Ishraq participants; an option to enter school for those girls who attain their literacy certificate; and an annual village campaign to ensure that all children have birth certificates, access to health insurance, and national identification cards by the legal age of 16 .

A parallel "family contract" is envisioned in which parents will agree to have their daughters complete the full program even if they become engaged. Agreement will also be sought from both the girls and their parents that participants will be present for at least 80 percent of the scheduled program activities. These "contracts" will signal the seriousness and expectations of this initiative and, where resources are limited, help select the most highly motivated communities for investment.
>>Final Thoughts: Ishraq as a Vehicle of Change in Socially Conservative Societies

In the absence of intervention, poor, rural, unschooled girls in conservative and lowincome communities throughout West Asia and North Africa, and indeed elsewhere, are destined to a life of poverty, illiteracy, early marriage, high fertility, and poor health. Ishraq has altered this scenario in Upper Egypt by intervening early (around the time of puberty) with a welldesigned, multi-dimensional skill-building program.

There are many potential Ishraq villages around the world. Many other developing countries are also codifying a variety of rights and funding a host of opportunities theoretically available to girls whom they cannot yet reach. The challenge for Ishraq is to link these girls, their families, and communities to the widening opportunities and rights structures of their countries through political participation, strong partnerships, and effective links among civil society, local and national governments, and NGOs.

If the emerging international consensus on the Millennium Development Goals and national constitutions exert pressure from the top, the rights and aspirations of poor girls supply pressure from the grass roots. In between are private and public partnerships such as Ishraq, sustained by creative and flexible donors and by a time frame sufficient to allow change to take hold. For Egypt-and many other countries in the process of change-this is a historic period of reform and redefinition of citizenship, a concerted attempt to eliminate poverty. There can be no success in any of these arenas without the inclusion of the girls still left behind. 


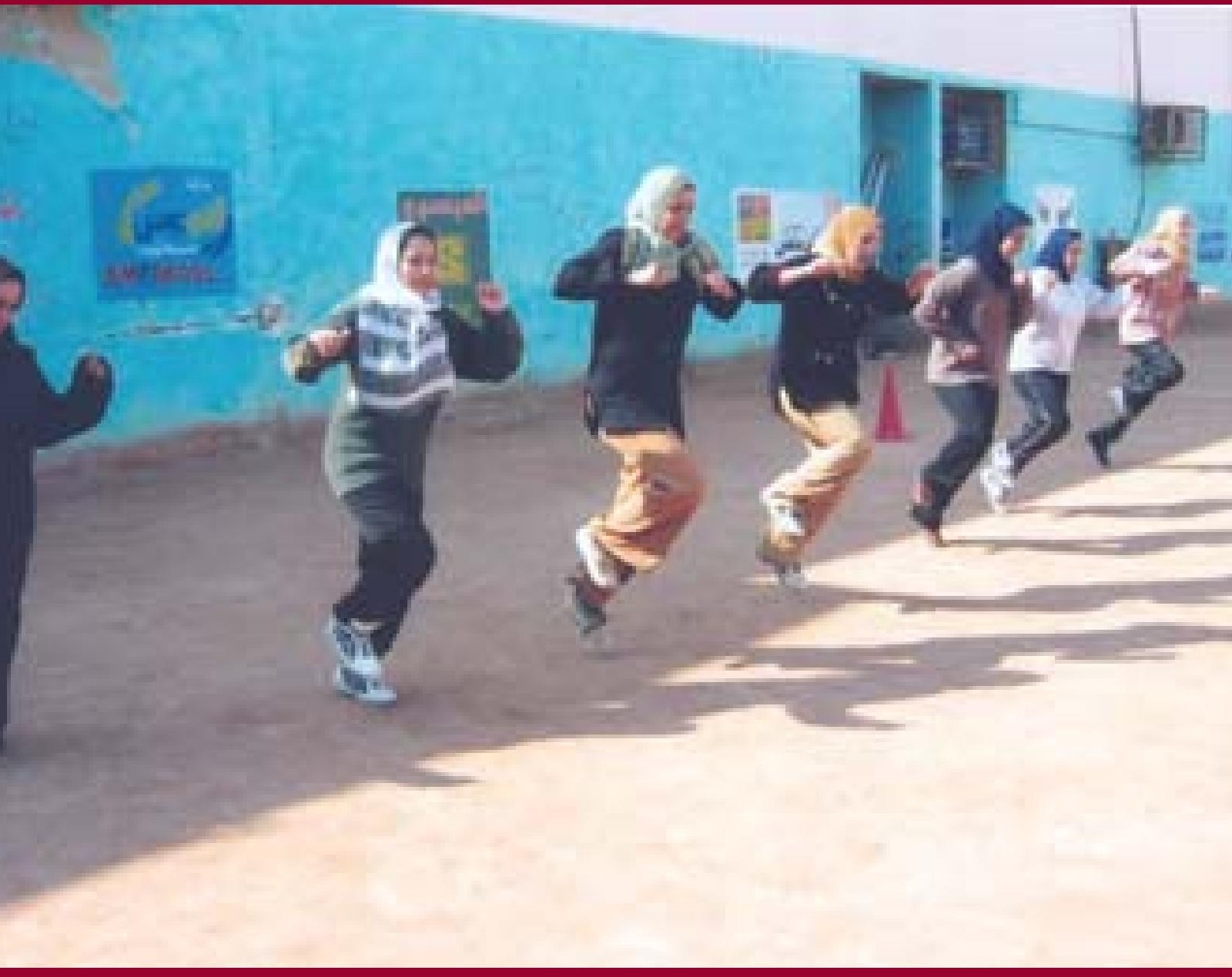

As Egypt enters a critical period of reform and redefinition of citizenship, it is vital that adolescent girls are included as a central part of the process. 
Ishraq program collaborators: Caritas, Center for Development and Population Activities (CEDPA), Population Council, Save the Children

Governmental partners: Ministry of Youth (Supreme Council for Youth), National Council for Childhood and Motherhood

Donors: Department for International Development (DFID), the Dickler Family Foundation, the Ford Foundation/Egypt, the Bill and Melinda Gates Foundation, Nike Foundation, United Nations Children's Fund/Egypt (UNICEF/Egypt)

Written by: Martha Brady, Ragui Assaad, Barbara Ibrahim, Abeer Salem, Rania Salem, and Nadia Zibani

All photographs courtesy of Nadia Zibani

The Population Council, an international, nonprofit, nongovernmental organization, seeks to improve the well-being and reproductive health of current and future generations around the world and to help achieve a humane, equitable, and sustainable balance between people and resources.

For more information about the Council's programs, visit www.popcouncil.org.

C2006 The Population Council, Inc.

Population Council

One Dag Hammarskjold Plaza, New York, NY 10017 www.popcouncil.org

www.popcouncil.org/pdfs/IshraqReport.pdf

www.popcouncil.org/pdfs/IshraqFullReport.pdf 
Adolescence represents the last opportunity to prepare girls for the challenges of adulthood.

Failure to reach girls now may well doom them to lives of isolation, poverty, and powerlessness. It also may be their last chance for organized learning and play. In rural Upper Egypt, participation in the Ishraq program provides disadvantaged girls the opportunity for structured learning, mentoring, and participation in community life.

(1) Population Council 